\title{
OD NAČELA ZAVIČAJNOSTI DO OTVORENOG METODIČKOG SUSTAVA
}

\author{
Mirjana Benjak i Marko Ljubešić: Od Peruška do otvorenog sustava \\ Zagreb, Školska knjiga, 2013.
}

U rijetkim akademskim sredinama uopće, a pogotovo danas, posvećujemo pozornost onima koji su utirali put određene struke i ostavili trajan pečat u njoj. Upravo suprotno pokazuje monografija profesora pulskog Odsjeka za kroatistiku Mirjane Benjak i Marka Ljubešića Od Peruška do otvorenog sustava, koju je 2013. godine objavila Školska knjiga iz Zagreba. U Predgovoru autori navode nekoliko poticaja za njezino objavljivanje. Prvi su poticaj bila obilježavanja nekih bitnih događanja vezanih uz rad istaknutoga književnika, publicista, kulturnoga, prosvjetnog, društvenopolitičkog i znanstvenog djelatnika Tone Peruška (19051967). On je bio utemeljitelj (1961) i direktor (do svoje smrti 1967) prve nastavničke visokoškolske institucije na hrvatskome jeziku u Istri - Pedagoške akademije u Puli, čija je 50. godišnjica obilježena 2011. godine. Prošlo je, također, i 50 godina od objavljivanja Peruškove najvažnije metodičke knjige Materinski jezik u obaveznoj školi (Specijalna didaktika) - prve metodičke monografije koja je doživjela šest izdanja, a bavila se svim relevantnim područjima nastave materinskoga jezika i književnosti. Da toj monografiji pripada važno mjesto u povijesti metodike hrvatskoga jezika, potvrđuju i riječi Milivoja Gabelice izrečene prije dvadesetak godina - riječ je, naime,o najkompletnijoj i najboljoj metodici materinskoga jezika na koju su se osvrtali mnogi vrsni metodičari. Nadalje, prošlo je i 45 godina od objavljivanja Peruškovih skripta Nastava o zavičaju. Peruško je, naime, učinio još jedan važan, u hrvatskim okvirima pionirski korak - na Pedagoškoj akademiji u Puli utro je put uvođenju posebnoga predmeta - nastave o zavičaju, suočivši se s negativnim stajalištima u tadašnjim znanstvenim i političkim krugovima. Da je Peruško bio i te kako u pravu uvodeći načelo zavičajnosti, potvrđuju i poznati hrvatski metodičari (npr. Stjepko Težak, Dragutin Rosandić i dr.) koji su, oslanjajući se na Peruškova načela, i sami promicali zavičajnost u jezičnom i književnom odgoju i obrazovanju. Pišući o načelu zavičajnosti, Težak smatra da ulazak „u opću nacionalnu svjetsku kulturu nije normalan ako se jedna stepenica preskače, tj. ako se mimoilazi zavičajna kultura. Dijete svjesno kulture svoje uže sredine lakše će i 
s izoštrenijim kriterijima prihvaćati tekovine opće kulture“"1. Da zavičajna kultura zauzima važno mjesto na Odsjeku za kroatistiku Odjela za humanističke znanosti Sveučilišta Jurja Dobrile u Puli (koji i baštini ostavštinu Tone Peruška), pokazuje i činjenica da je zavičajna književnost ne samo zaseban kolegij na diplomskome studiju jezika i književnosti nego je integrirana i u druge kolegije. Pohvalno je, također, da su autori ove monografije novoosnovanu katedru nazvali Katedrom za metodiku hrvatskoga jezika i književnosti „Tone Peruško“, pokazavši time aktualnost Peruškovih metodičkih ideja i stajališta i danas, posebno onih koja se tiču načela zavičajnosti u nastavi.

Monografija je podijeljena na dva dijela. Prvi dio naslovljen Na tragu zavičajnosti Tone Peruška donosi u sedam poglavlja dvije skupine priloga. U prvoj se skupini priloga raspravlja o Peruškovom načelu zavičajnosti, a prilozi u drugoj skupini zapravo proizlaze iz toga načela. U prvome poglavlju s naslovom Načelo zavičajnosti u metodici Tone Peruška autori, uzimajući u obzir tadašnji društveno-politički kontekst, govore o važnosti osnivanja Pedagoške akademije u Puli i ulozi T. Peruška pri tome, pogotovo njegovog nastojanja da se od samoga početka vodilo računa i o talijanskom etnosu, što je ostalo do danas (na Sveučilištu Jurja Dobrile u Puli školuju se nastavnici na Odjelu za humanističke znanosti - Odsjek za kroatistiku i Odjelu za studij na talijanskom jeziku). Autori nadalje detaljno predstavljaju poglavlja metodičke monografije Materinski jezik u obaveznoj školi (Specijalna didaktika) upozoravajući na njezinu aktualnost, sustavnost, metodičku inventivnost i znanstvenu zasnovanost. Kao što je Peruško imao nemalih problema pri osnivanju Akademije, tako se s negativnim stajalištima suočio i pri uvođenju predmeta Nastava o zavičaju, na što su ga naveli politički razlozi. Naime, Istra se, parafrazirajući Peruška, tek 1945. u cijelosti pridružila matici zemlje, a po etničkom sastavu ona je višenacionalna: i hrvatska, i slovenska, i talijanska, pa čak i rumunjska. Na kraju poglavlja autori kritički govore o Peruškovoj zavičajno-metodičkoj koncepciji u kontekstu sveučilišnog studija na pulskom Odsjeku za kroatistiku predstavljajući niz kolegija (obaveznih i izbornih) u kojima se pojavljuje zavičajnost, ali upozoravajući da je zavičajna nastava danas ponajprije svedena na sadržaje vezane za studij jezika i književnosti - za razliku od Peruška koji je zavičajnu nastavu osmislio interdisciplinarno (zavičajnim temama pristupao je ne samo u sklopu nastave jezika i književnosti nego i u sklopu sadržaja iz povijesti i gospodarstva). Autori zaključuju da bi suvremeno istarsko školstvo (i osnovno, i srednje, i visoko) trebalo imati veći oslonac u zavičajnosti, a temeljni subjekt u promicanju zavičajnih vrijednosti trebalo bi biti Pulsko sveučilište.

$\mathrm{Na}$ početku drugoga poglavlja (Zavičajna književnost kao književnoteorijski, književnopovijesni i metodički problem) autori postavljaju (i na njih odgovara1 Težak, S. (1984). Gramatika u osnovnoj školi. Zagreb: Školska knjiga, 155. 
ju) tri pitanja: Što je zavičaj?, Tko su zavičajni književnici? i Koja djela smatramo zavičajnima? Iako je u metodičkoj znanosti termin zavičajna književnost prisutan od druge polovice 20. stoleća, u ovoj je monografiji on drukčije shvaćen i definiran. Zavičajna se književnost određuje ,prema tematskoj pripadnosti određenoga djela te prema pripadnosti rodnom kraju autora" (19); pod istarskom zavičajnom književnošću podrazumijevaju se ,sva djela koja obrađuju temu istarskog zavičaja, neovisno o jeziku kojim su pisana, te autore koji su rodom iz Istre, neovisno o tome kojim se jezikom (ili idiomom određenoga jezika) služe u svojim književnim djelima“" (19). Prema tome zavičajnu književnost Istre mogu činiti djela pisana različitim standardnim jezicima (hrvatskim, talijanskim, slovenskim) i mjesnim idiomom (čakavskoga narječja, istrovenetski dijalekt, primorska skupina narječja), kao i ostalim jezicima nacionalnih manjina prisutnih u Istri (crnogorski, rumunjski, albanski, srpski itd.). Nakon predstavljanja istarske zavičajne književnosti u sklopu hrvatske književne historiografije autori navode rezultate istraživanja položaja istarske zavičajne književnosti u hrvatskom školskom sustavu. Zanimaju ih, prije svega, stajališta učenika i nastavnika hrvatskoga jezika o problematici istarskih zavičajnih sadržaja u nastavi materinskoga jezika.

U trećem poglavlju (Jezične kompetencije budućih učitelja i nastavnika hrvatskog jezika za rad u višejezičnoj sredini) autori odgovaraju na pitanje priprema li studij učitelje i nastavnike za rad u višejezičnoj sredini. Analiza nastavnih programa hrvatskog jezika na preddiplomskom i diplomskom studiju hrvatskoga jezika i književnosti na Odsjeku za kroatistiku Sveučilišta Jurja Dobrile u Puli pokazala je nedostatak studijskih sadržaja potrebnih za kvalitetno uvođenje budućih učitelja i nastavnika u nastavni proces. Rezultati empirijskog istraživanja sa studentima pokazali su veliku toleranciju studenata u prihvaćanju manjinskih jezika, ali i upozorili na potrebu korekcije studijskih programa, posebno u kolegijima koji promiču razdvajanje jezičnih djelatnosti potrebnih za rad u višejezičnoj sredini. Kako odlučujuću ulogu u osposobljavanju mladih za život i rad u višejezičnoj i višekulturnoj sredini, kakva je Istra, imaju književni i jezični sadržaji, autori nadalje raspravljaju o jezičnim koncepcijama budućih učitelja hrvatskog jezika za rad u takvim sredinama i odgovaraju na pitanje kako se učenici s dvojezičnog područja odnose prema talijanskom kao jeziku sredine (Funkcioniranje i recepcija L2 kod gimnazijalaca u dvojezičnoj sredini, na Bujštini, u Istri).

Proizlazeći i nadograđujući načelo zavičajnosti, uzimajući u obzir specifičnosti istarskoga višejezičnog i višekulturnog prostora i rezultate suvremene metodičke znanosti te, što posebno ističemo, rezultate empirijskih istraživanja, prilozi druge skupine prvoga poglavlja donose tri metodička modela književnih djela istarske književnosti (pisana na hrvatskom, talijanskom i slovenskom jeziku), i to u sklopu suvremenih metodičkih sustava. U prvom modelu riječ je o 
interpretaciji Tomizzina romana Materada s posebnim naglaskom na lingvostilističkoj analizi (Interpretacija romana iz istarske književnosti na talijanskom jeziku /Fulvio Tomizza: Materada/). Školska interpretacija romana predviđena je za učenike u III. razredu gimnazije koji žive na dvojezičnom području (na Bujštini), ali ona naravno može poslužiti kao primjer ostalim sličnim sredinama. Uzimajući u obzir bilingvizam učenika (većina ih se služi dijalektom talijanskog jezika - il veneto - i hrvatskim jezikom, te u manjoj mjeri čakavskim dijalektom), autori su povezivanjem nastave jezika i nastave književnosti željeli potaknuti produktivnu, receptivnu i komunikativnu djelatnost učenika s ciljevima da oni dožive jezik književnosti kao zasebnu manifestaciju, da uočavaju stilogene postupke u jeziku književnoga djela te da ga analiziraju prema lingvističkim i stilističkim kategorijama. Drugi metodički model posvećen je romanu Šavrinke ${ }^{2}$ Marjana Tomšiča (Interpretacija romana iz istarske književnosti na slovenskom jeziku /Marjan Tomšič: Šavrinke) i obrađen u sklopu nekonvencionalnih oblika nastave ${ }^{3}$. Osim što su pri interpretaciji romana autori vodili računa da je roman na slovenskom jeziku i da nije preveden na hrvatski, također su vodili računa i o aktualizaciji romana i time izbjegli eventualne prepreke zbog vremenskog odmaka i velikih promjena u načinu života Istre nekada i danas. Nakon samostalnoga usmjerenog čitanja romana, njegova je interpretacija zamišljena u tri dijela: u prvome dijelu na jezično-stilskoj razini, u drugome dijelu na razini likova, a u završnom dijelu bila je ekskurzija „Putevima Šavrinki“. Ekskurzija kao nekonvencionalni oblik, u skladu s otvorenim metodičkim sustavom, uključuje sadržaj (itinerarij putovanja i mjesta koja će posjetiti, npr. Motovun, Buzet, Gračišće, Trst, Kopar itd.) i zadatke tijekom ekskurzije koje su učenici odabrali (npr. vođenje dnevnika ekskurzije, biranje ulomaka koji će se čitati na pojedinim mjestima...). Takav oblik nastave zanimljiv je naročito pri interpretaciji djela koja opisuju stvarna mjesta, kao i djela koja imaju u osnovi realistične priče o ljudima i običajima određenog dijela zavičaja. Treći model posvećen je interpretaciji Istarskog razvoda 4 u sklopu inter-

2 Šavrinke su bile slovenske Istranke koje su po Hrvatskoj prikupljale jaja, nosile ih pješice do Trsta, gdje su ih prodavale i za taj novac kupovale ono što je ljudima na selu bilo potrebno (sol, sapun, platno...). Njihova je »trgovina« bila jako naporna, a zarada minimalna; radile su i petkom $\mathrm{i}$ svetkom - od sedam dana u tjednu pet bi pješačile.

3 To su oblici nastave koji omogućuju uključivanje interkulturalnih sadržaja u odgojno-obrazovni proces; „nekonvencionalni“ su po svome cilju (unapređivanje učenikove stvaralačke ličnosti) i po organizaciji. Dijele se prema mjestu izvođenja (muzeji, galerije, kazališta, kulturno-povijesni spomenici...), prema trajanju (jednosatni, dvosatni, jednodnevni, višednevni...) i prema nastavnim predmetima (književni, jezični, glazbeni, povijesni...). Termin su uvele Mirjana Benjak i Vesna Požgaj Hadži.

4 Istarski razvod je hrvatskoglagoljski spomenik, odnosno pravna isprava iz 1325. u kojoj se govori o razgraničenju posjeda (»termena i kunfina«) između pojedinih istarskih seoskih općina, njihovih feudalnih gospodara i Mletačke Republike. U 21 dan razvodna je komisija prešla oko 150 
disciplinarnog (integracijsko-korelacijskog) i sustava projektne (terenske) nastave (Istarski razvod bez »kunfina" /povijesni, društveno-povijesni i književni aspekti spomenika u nastavi/). Takav izbor metodičkih sustava i aktualizacija teksta leži u činjenici da je još uvijek jedan od problema metodičke teorije i prakse nastava starijih, srednjovjekovnih tekstova (problem motivacije, recepcije, te interpretacije). Osim toga naglasimo da projektni sustav omogućuje učeniku slobodan odabir tema i obrađivanje pojedinih zadataka, a nastavnik, za razliku od tradicionalnoga pristupa, koordinira nastavni proces i pomaže u svakoj etapi projektne nastave te organizira sistemizaciju i vrednovanje. Predstavljene etape projektne nastave (od uvodnoga sata na kojem se Istarskome razvodu pristupa kao pravnome, povijesnome, jezičnom/književnom spomeniku s naglaskom na njegovoj aktualizaciji, usmjerenoga čitanja teksta, osmišljavanja projektnog itinerarija i podjele zadataka, terenske nastave pa sve do analize projektne nastave) pobuđuju ne samo interes još neizgrađenih čitatelja za stariju književnost nego i motiviraju učenike za bavljenje književnošću uopće.

Svako raspravljanje o nastavi jezika i književnosti vraća nas temeljnim pitanjima koja se odnose na određivanje ciljeva te nastave, njezinoj obrazovnoj i odgojnoj ulozi. Upravo iz koncepcije obrazovnih i odgojnih ciljeva nastave, te njezine kulturološke i društvene funkcije proizlaze različiti metodički sustavi kojima je posvećen drugi dio monografije pod naslovom Suvremeni metodički sustavi u nastavi hrvatskoga jezika i književnosti. U sklopu korelacijsko-integracijskoga, problemsko-stvaralačkog, komunikacijsko-komparativnog, multimedijskog i otvorenog metodičkog sustava autori donose metodičke modele za obradu književnih (hrvatskih i svjetskih) i jezičnih sadržaja. Razlozi odabira obrade zen-priče (osmo poglavlje) obrađene u sklopu dvaju sustava: Dan zen-priče (korelacijsko-integracijski sustav i problemsko-stvaralački sustav) bili su ovi: a) u hrvatskim nastavnim programima i udžbenicima (od 1960-ih godina nadalje) rijetko se pojavljivala književnost Dalekog istoka, b) nastava svjetske književnosti morala bi biti zastupljena proznim djelima i izvan evropskoga, odnosno američkog kulturnog kruga, c) daleki svijet prisutniji je u svakidašnjem životu, pa time postoji i veliko zanimanje učenika za književnosti dalekih civilizacija. Deveto poglavlje posvećeno je problemu hiperteksta u nastavi (Metodički pristup hipertekstu / problemsko-stvaralački sustav/) - autore je zanimalo kako istražiti „popularnost““ hipertekstualnog književnog oblika među učenicima i kako ,prilagoditi“ nastavne programe suvremenim dostignućima. Na pitanje o zastupljenosti književnika u

km spornoga terena; na tom prohodu pratila su je tri notara koje su gospoda odabrala, kao što piše u na samom početku teksta, ,jednoga latinskoga, a drugoga nemškoga, a tretoga hrvackoga“. Po svojoj pravnoj i književnoj vrijednosti može se ubrojiti u najzanimljivije dokumente toga doba u Europi. 
nastavnim programima susjeda, konkretnije Hrvata i Slovenaca, odgovara se u poglavlju Hrvatsko-slovenski književni dodiri u gimnazijskoj nastavi (problemsko-stvaralački sustav), koje i nudi metodički model kojim se nastoji ispraviti nerazmjere u učenju susjedne književnosti. Nakon interpretacije Cankareve novele u sklopu problemsko-stvaralačkog sustava autori donose rezultate istraživanja u kojem zaključuju da među učenicima postoji zainteresiranost za bolje upoznavanje susjednih književnosti, konkretno slovenske. O položaju, odnosno (ne)prisutnosti Ivana Mažuranića i Petra P. Njegoša u hrvatskim gimnazijskim programima (a time i u udžbenicima) od 1970-ih do danas raspravlja se u 11. poglavlju s naslovom Jesu li Mažuranić i Njegoš maturirali? (komunikacijsko-komparativni sustav). Polazeći od kriterija za izbor književnih sadržaja, autori zaključuju da su u svim programima prisutni književnopovijesni, estetski i žanrovski kriterij, a, nažalost, zanemareni recepcijski kriterij i kriterij učeničkih interesa i privlačnosti. Uzimajući u obzir navedeno i primjenjujući načela aktualizacije, autori pristupaju Mažuranićevu djelu Smrt Smail-age Čengića u sklopu komunikacijskog sustava, a interpretaciji Njegoševa Gorskog vijenca u sklopu komparativnog sustava zaključujući da bi sastavljači budućih programa morali voditi računa o književnim interesima učenika, njihovim recepcijskim i kognitivnim mogućnostima, o načelu aktualizacije, te više pozornosti posvećivati učeničkoj kreativnosti uvodeći metodičke sustave i postupke koji će poticati učenikov samostalan istraživački rad. U 12. poglavlju (Računalom kroz nastavu hrvatskoga jezika i književnosti / multimedijski sustav/) autori teorijski i primijenjeno obrađuju primjenu osobnog računala u nastavi hrvatskoga jezika (sinteza nezavisnosloženih rečenica u 7. razredu osnovne škole) i književnosti (interpretacija pjesme Opomena Antuna B. Šimića). Što se metoda tiče, spominju se dijaloška, istraživačka, učenje s pomoću rješavanja problema, simuliranje i igra, a od oblika govori se o individualnom obliku rada, radu u parovima, skupnom i zajedničkom radu. Posljednje, 13. poglavlje, monografije (Luko Paljetak: Skroviti vrt lotvoreni sustav/) posvećeno je otvorenome sustavu koji možemo ubrojiti u nove metodičke sustave (uz komunikacijski, multimedijski i timski). On se sastoji od četiri dijela: didaktičke ponude (dijeli se na sadržaj, metode i oblike rada), istraživačkog rada (individualnog, u paru i grupnog), objavljivanja rezultata (komunikacijski oblici, oblici usmenog i pisanog izražavanja, sustav i kriteriji vrednovanja rezultata) i novi (istraživački i stvaralački) zadaci. Taj je sustav ilustriran na primjeru interpretacije romana Luke Paljetka Skroviti vrt u IV. razredu gimnazije. Razlozi odabira romana bili su ovi: roman govori o zagonetnoj, obrazovanoj i prelijepoj plemkinji Cvijeti Zuzorić (16-17. st.), kojoj su mnogi hrvatski i evropski književnici i filozofi posvećivali radove; njegovo objavljivanje 2004. pobudilo je veliko zanimanje čitatelja i kritike. Roman se, zahvaljujući svojoj jezičnoj, filozofskoj i poetskoj razini, ubraja 
među najbolja djela u hrvatskoj književnosti; privlačan je za mlađe čitatelje; roman može poslužiti kao izazov za interpretaciju u završnom razredu gimnazije. U komunikaciji koju otvoreni sustav predlaže (književno djelo - učitelj - učenik), učenik je aktivni subjekt $u$ nastavnome procesu koji čita, analizira, interpretira $i$ vrednuje književnoumjetničko djelo.

Kao što vidimo, već sam izbor autora koji se obrađuju u metodičkim modelima pokazuje interkulturalni stav Mirjane Benjak i Marka Ljubešića, koji je prisutan u cijeloj monografiji. U njoj se nadalje prepoznaju stavovi Zagrebačke metodičke škole (i njezina utemeljitelja Dragutina Rosandića) koje autori proširuju svojim viđenjem, spretno spajajući teorijsko poznavanje metodičkih sustava s njihovom primjenom. Da se podsjetimo, sedamdesetih godina afirmiran je interpretativno-analitički metodički sustav (književno djelo postaje temeljnim sadržajem nastavnog procesa, učenik je estetski subjekt, a učitelj organizator procesa) koji je i danas najčešći u hrvatskim školama. 1980-ih se godina pojavljuje problemsko-stvaralački sustav (učenik samostalno istražuje određeni problem, a od učitelja se traži opsežna priprema i umješnost organizacije) i korelacijsko-integracijski sustav (povezivanje nastavnih područja). Suvremena metodička teorija kasnije uvodi komunikacijski metodički sustav (utemeljen je na teoriji didaktičke i literarno-estetske komunikacije), multimedijski sustav (uključuje različite medije kojima se prenose poruke), timski sustav (izrasta iz načela interdisciplinarnosti) te otvoreni sustav (didaktička je komunikacija utemeljena na ponudi sadržaja, metoda i oblika za učenikovo samostalno učenje, istraživanje i stvaranje).

Zavičajna književnost ovom monografijom dobiva drukčiju ulogu u jezičnom i književnom odgoju i obrazovanju. Još jednom ističem njezinu teorijsko-primijenjenu vrijednost; teorijske postavke, koje su primarne, autori uvijek provjeravaju u metodičkim modelima i dosljedno provode svoje prepoznatljivo viđenje metodike jezika i književnosti (po čemu su odavno nadmašili granice Istre i Hrvatske) pokazujući ispreplitanje različitih metodičkih sustava i nove mogućnosti realizacije književnih i jezičnih sadržaja u nastavi. Prikazane nove smjernice potiču učitelje/studente na nove modele, učenike podižu na razinu sustvaratelja u nastavi, a stručnjake pozivaju na kritičko čitanje i vrednovanje. Iz monografije se dadu iščitati mjere unapređivanja književnoj odgoja i obrazovanja koje se odnose na: a) programiranje (uključivanje zavičajne književnosti i primjenu teorije kurikula), b) redefiniranje ciljeva književnog i jezičnog odgoja i obrazovanja u skladu s načelima slobode izbora, demokracije, nacionalnog identiteta, interkulturalizma, multikulturalizma, c) oblikovanje udžbenika i drugih didaktičkih izvora, d) fleksibilniju organizaciju nastave, e) stvaralački položaj učenika i učitelja i f) pluralizam metodičkih sustava. Oslanjajući se na suvremene metodičke teorije srednjoškolske nastave jezika i književnosti, te primjenu teorije interkulturalne 
komunikacije te provjerenu mogućnost primjene u jezičnom i književnom odgoju i obrazovanju, monografija donosi primjere interpretacije koji će pridonijeti osuvremenjivanju književnoga i jezičnog odgoja i obrazovanja.

Kako je zavičajna književnost u srednjoškolskom jezičnom i književnom odgoju zanemarena, kako u metodičkim publikacijama ima premalo konkretnih metodičkih modela obrade književnih i jezičnih sadržaja u sklopu suvremenih metodičkih sustava, metoda i oblika, sigurna sam da će ova monografija biti dobar vodič kroz zavičajnu književnost. Nastavnicima/profesorima jezika i književnosti (od osnovnoškolskih do fakultetskih) bit će inspiracija za vlastiti stvaralački rad (i to ne samo u Istri), a studentima kroatistike (ali i drugih studijskih grupa), kao što kažu autori u Predgovoru, ,putokaz za prve korake u složenom procesu jezičnog i književnog obrazovanja primjenjujući načelo zavičajnosti i suvremene metodičke sustave u svom budućem nastavničkom radu“ (5). Ukratko, riječ je o monografiji koja je i vodič i putokaz u odgoju mladih u duhu prihvaćanja i razumijevanja Drugog i Drukčijeg. Parafrazirajući autore, bez poznavanja kulturne raznolikosti nemoguća je interkulturalna komunikacija, nužna u suvremenom društvu, a nastava jezika književnosti može i te kako pomoći u njezinu promicanju.

Vesna S. Požgaj Hadži Sveučilište u Ljubljani, Filozofski fakultet 